\title{
Evidensbevægelsens institutionalisering og arbejdsformer
}

\section{Af Hanne Foss Hansen og Olaf Rieper}

\begin{abstract}
Evidensbevagelsen producerer en ny type viden $i$ form af systematiske forskningsoversigter. Artiklen satter fokus på den institutionaliserede del af evidensbevagelsen, der beskaftiger sig med at producere systematiske forskningsoversigter med scerligt henblik på det sundheds- og socialpolitiske område. I denne artikel vil vi adressere spørgsmålene: Hvad er evidensbevagelsens adelsmarke? Hvordan kom den ind $i$ de skandinaviske lande? Er der tale om simpel kopiering fra det medicinske område med en smal selektion af primoere studier som grundlag for forskningsoversigter, eller er sagen mere indviklet?
\end{abstract}

\section{Indledning}

Begrebet evidens har i de seneste årtier tiltrukket sig fornyet og stærkt voksende interesse. Evidensbaseret politik, evidensbaseret praksis (medicin, velfærd, socialt arbejde, uddannelse mv.), evidensbaseret ledelse ja, evidensbaseret alt-muligt er blevet et plusord.

Evidensbasering handler om at udarbejde politik, udøve praksis etc. med afsæt $\mathrm{i}$ den bedst mulige viden om, hvilke indsatser der virker. Da evidens ikke er et entydigt begreb, er debatten om evidenstankegangen intensiv og ofte ganske polariseret. Fortalerne for tankegangen ser store fordele $i$ at indarbejde evidenstankegangen i alle dele af den offentlige sektor, og fortalerne ser flere potentialer:

"Evidenstankegangen passer godt til flere af de udfordringer, som den offentlige sektor står overfor fremover... Evidens kan blive et afgørende bidrag til et prioriteringssprog... Evidenstankegangen kan blive et markant kvalitetsløft og være et nyt grundlag for dialogen med brugere og brugerorganisationer... Evidens kan blive et løft for offentlig ledelse." (Mandag Morgen, 2004, s. 10-11).

Kritikerne er endog særdeles skeptiske. De taler om et "tal- og kontrolgruppetyranni" (Lihme, 2005b, s. 2) og om "kulturkamp" (Lihme, 2005a, s. 52). Se kapitlet i dette nummer (side 17) af Carl Gustav Johannsen, som beskriver de kritiske argumenter imod evidens. 
Vi vil i det følgende forsøge at gå bag om denne til tider noget unuancerede debat. Vi vil diskutere begrebet evidens samt præsentere den vifte af arbejdsformer, der tilbyder sig i relation til produktionen af evidens. Vi vil herudover give et overblik over evidensbevægelsens baggrund og udvikling. Vi vil særligt sætte fokus på den del af evidensbevægelsen, der arbejder med at producere viden om, hvilke indsatser der virker henholdsvis ikke virker via udarbejdelse af sammenfatninger af flere undersøgelser og forskningsarbejder, de såkaldte "reviews", på dansk "forskningsoversigter". Særligt udviklingen inden for sundhedsområdet samt det social- og velfærdspolitiske område vil være i fokus, fordi der på disse områder er udviklet den mest institutionaliserede praksis.

Vi vil i denne sammenhæng søge at besvare følgende spørgsmål:

1. Hvordan er evidensbevægelsen kommet til Skandinavien?

2. Hvordan er evidensbevægelsen organiseret?

3. Hvad karakteriserer dens arbejdsform?

4. Hvordan skal den øgede interesse for evidens tolkes? Er evidensbevægelsen udtryk for en ny form for vidensproduktion? Er den et nyt lag i den New Public Management-inspirerede forvaltningspolitik, der er rullet frem siden starten af 1980'erne? $\mathrm{Og} / \mathrm{eller}$ er den en ny legitimeringsstrategi for professionerne?

Ud over den hastigt voksende litteratur om evidens bygger kapitlet på analyse af dokumentarisk materiale, herunder frem for alt de evidensproducerende organisationers egen præsentation af deres organisering og arbejdsform, deltagelse på konferencer og seminarer om evidens samt interview med centralt placerede respondenter. ${ }^{1}$

Kapitlet er struktureret på den måde, at vi først, i afsnit to, diskuterer evidensbegrebet og præsenterer den vifte af arbejdsformer, som litteraturen tilbyder til produktion af evidens. Herefter zoomer vi i afsnit tre ind på evidensbevægelsens baggrund, institutionalisering og arbejdsform. Endelig indeholder afsnit fire diskussionen af, hvordan udviklingen kan tolkes.

\section{Hvad er evidens, og hvordan kan det tilveje- bringes?}

I den hastigt voksende internationale litteratur om evidens understreges det, at evidensbegrebet har flere ansigter. Evidens antager forskellige former og vurderes forskelligt i forskellige kontekster, i det juridiske system, i naturvidenskaben, i medicin og i fx humaniora, og evidensbegrebets indhold diskuteres $\mathrm{i}$ fag som fx medicin og psykologi og blandt professionsgrupper, fx socialrådgivere.

Gennemgående anføres tre kriterier som gennemgående for vurdering af evidens: 1) relevans i forhold til et givent udsagn, 2) tilstrækkelighed i betydningen overensstemmelse med andre typer af evidens samt 3) sandfærdighed defineret som upartiskhed (Thomas, 2004, s. 1). Ofte sondres der i litteraturen også mellem forskellige former for evidens fx mellem forskningsbaseret evidens, anden videnskabelig evidens og praksis-baseret evidens (Eraut, 2004, s. 92) eller mellem global evidens, forstået som viden, der generaliserer sine resultater over et bredt felt, modsat lokal evidens, forstået som viden baseret på en stærk kontekstopmærksomhed (Moos et al., 2005, s. 54-55). Evidensbasering, fx evidensbaseret praksis, anskues ikke nødvendigvis som bevisbaseret praksis, men snarere som praksis, der er en vis grad af belæg for virker (Marthinsen, 2004, s. 292).

Ligesom evidensbegrebet ikke er entydigt, er der heller ikke en entydig arbejdsform knyttet til produktionen af evidens. Alene forskningsbaseret evidens kan tilvejebringes på mange måder. I litteraturen listes der således både en lang række typer af forskningsoversigter ("reviews") og en vifte af arbejdsformer, ved hjælp af hvilke evidens kan syntetiseres fra enkeltstående undersøgelser (Petticrew \& Roberts, 2006, kapitlerne 2 og 6). De væsentligste typer af forskningsoversigter og de væsentligste arbejdsformer til syntese af forskningsresultater er beskrevet $\mathrm{i}$ figur 1.

Der er i forskersamfundet en lang tradition for udarbejdelse af klassiske forskningsoversigter. Sådanne indgår i større eller mindre omfang i stort set alle afhandlinger og undersøgelser. De øvrige og nyere typer af forskningsoversigter, frem for alt de systematiske forskningsoversigter, adskiller sig fra de klassiske ved at følge nøje beskrevne procedurer for søgning, udvælgelse og syntetisering af primærstudier samt procedurer for kvalitetssikring af disse. Arbejdsprocessen er organiseret i en række faser: 1) Formulering af problemstillingen, 2) systematisk søgning, 3) kritisk vurdering af enkeltstudier og 4) syntetisering af resultaterne. Herudover varierer de 


\begin{tabular}{|l|l|}
\hline Typer af forskningsoversigter & Definition \\
\hline Systematisk forskningsoversigt & $\begin{array}{l}\text { En forskningsoversigt, der søger at identificere alle relevante undersøgelser (primær- } \\
\text { studier), der kan bidrage til at besvare, om en konkret indsats/behandling virker. Va- } \\
\text { liditeten af hver enkelt undersøgelse vurderes, og denne tages i betragtning, når kon- } \\
\text { klusionerne om indsatsens resultater drages. Oftest benyttes meta-analyse (statistisk } \\
\text { kalkulation), når resultaterne af de enkeltstående undersøgelser skal syntetiseres. }\end{array}$ \\
\hline Narrativ forskningsoversigt & $\begin{array}{l}\text { Anvendes som betegnelse for systematiske forskningsoversigter, som syntetiserer re- } \\
\text { sultater af flere enkeltstående undersøgelser narrativt (= fortællende/argumenterende) } \\
\text { snarere end ved hjælp af metaanalyse. }\end{array}$ \\
\hline Konceptuel forskningsoversigt & $\begin{array}{l}\text { En forskningsoversigt, der søger at syntetisere konceptuel (= begrebsmæssig) viden, } \\
\text { som kan bidrage til en bedre forståelse af den indsats, der er i fokus. En konceptuel } \\
\text { forskningsoversigt giver et overblik over ideer, modeller og diskussioner på et om- } \\
\text { råde. }\end{array}$ \\
\hline $\begin{array}{l}\text { Realistisk forskningsoversigt } \\
\text { (realistic review eller realist syn- } \\
\text { thesis) }\end{array}$ & $\begin{array}{l}\text { En forskningsoversigt, der syntetiserer alle relevante undersøgelser med sigte på at } \\
\text { producere generaliserbar viden om den program-teori, indsatsen er forankret i (snarere } \\
\text { end om resultaterne af indsatsen, som de systematiske forskningsoversigter gør). }\end{array}$ \\
\hline Klassisk forskningsoversigt & $\begin{array}{l}\text { Anvendes som betegnelse for bredere litteraturoversigter, der ikke anvender forma- } \\
\text { liserede systematiske arbejdsformer og ikke alene sætter fokus på resultaterne af en } \\
\text { given indsats. }\end{array}$ \\
\hline Kritisk forskningsoversigt & $\begin{array}{l}\text { Anvendes som betegnelse for litteraturoversigter, der vurderer en teori eller hypo- } \\
\text { tese ved kritisk at vurdere metoder og resultater af foreliggende undersøgelser uden at } \\
\text { bruge formaliserede systematiske arbejdsformer. }\end{array}$ \\
\hline
\end{tabular}

Figur 1. Oversigt over nogle vasentligt forskellige typer af forskningsoversigter og arbejdsformer til syntese (frit baseret på Petticrew \& Roberts 2006: 39 ff.)

nyere typer imidlertid med hensyn til sigte. Mens de systematiske forskningsoversigter fx sigter mod at vurdere, om indsatser og interventioner virker, sigter de realistiske forskningsoversigter mod at teste og udvikle programteorier (Pawson, 2002).

Der er ligeledes udviklet en vifte af arbejdsformer, ved hjælp af hvilke primærstudiernes resultater kan syntetiseres. Metaanalyse er en statistisk arbejdsform, der kræver tilgængelige kvantitative data helst tilvejebragt via lodtrækningsforsøg. De øvrige arbejdsformer muliggør, at andre typer af undersøgelsesdesign og datatyper kan inkluderes i syntesearbejdet. I narrativ syntese sammenfattes resultaterne argumenterende. I det, der kaldes "bedste evidenssyntese", syntetiseres resultaterne fra alle relevante undersøgelser uanset design under hensyntagen til de foreliggende undersøgelsers kvalitet. I denne tilgang kombineres fx kvantitative data vedrørende indsatsers outcome med kvalitative data vedrørende implementeringsprocesser.
Efter på denne måde at have præsenteret evidenstankegangens metodologiske "vifte", vil vi i det følgende afsnit vende os mod evidensbevægelsens praksis. Vi vil fokusere særligt på sundhedsområdet samt på det velfærds- og socialpolitiske område, fordi evidensbevægelsen her i et nordisk perspektiv er mest institutionaliseret.

\section{Evidensbevægelsens baggrund, institutionalise- ring og arbejdsform}

Evidensbevægelsens idémæssige grundlag kan føres tilbage det 19. århundrede. Nogle iagttagere anfører endog, at bevægelsen endda har rødder helt tilbage til tanker om udførelsen af kontrollerede forsøg inden for det medicinske område i 1700-tallet (Chalmers, 2001). Et vigtigt fundament for bevægelsen etableres i 1930'erne og 1940'erne, da man for alvor begynder at eksperimentere med kontrollerede lodtrækningsforsøg (Oakley, 2000). Ideen videreudvikles i 1970'erne, hvor epidemologen Archie Cochrane kritiserer medicinen for ikke at organisere viden på en systematisk, pålidelig og kumulativ måde med 
det resultat, at behandlinger ofte blev ineffektive, ja til tider ligefrem skadelige for patienter (Cochrane, 1999|1972). I forlængelse heraf lanceres i 1992 begrebet evidensbaseret medicin (EBM) i en artikel i Journal of the American Medical Association (JAMA) af en forskergruppe ved McMaster universitetet i Canada. Forskergruppen betegnede sig selv "The Evidence-Based Medicine Working Group" (Hult, 2006, s. 82).

Den institutionaliserede evidensbevægelse, forstået som etableringen af organisationer, der er specialiserede $\mathrm{i}$ at producere evidens, fik på denne baggrund sit udspring på det medicinske område med etableringen af det internationale Cochrane-samarbejde i 1993 (Oakley et al., 2005). Cochrane-samarbejdet udvikledes med afsæt i et internationalt forskningssamarbejde forankret på Oxford University, og flere af forfatterne bag artiklen i JAMA engagerede sig i Cochrane.

Senere blev tænkningen udbredt til andre områder. Cochranes søsterorganisation, det internationale Campbell-samarbejde, blev etableret i 1999 med fokus på områderne velfærd, uddannelse og kriminologi (Shadish, Chacón-Moscoso \& Sánchez-Meca, 2005). Beslutningen blev truffet på et møde i London, og samarbejdet blev formelt etableret i februar 2000 på et møde på University of Pennsylvania i USA. Initiativtager var blandt andre Robert Boruch, professor i uddannelse og statistik, samt forskere for University College i London. Samarbejdet tog navn efter den anerkendte amerikanske samfundsforsker Donald T. Campbell, kendt blandt andet fra hans tanker om det eksperimenterende samfund (Davies, 2004).

I Europa kan England karakteriseres som et foregangsland i udviklingen af evidensbevægelsen. Initiativerne til evidensbevægelsen er kommet fra universitetsmiljøer og har været drevet frem af enkeltpersoner. Men ideen har vundet politisk støtte. I England var Blairs Labour-regering således efterfølgende en central aktør i forhold til at udbrede forestillingen om evidensbasering til andre politikområder. I 1999 publicerede Blair-regeringen et White Paper med titlen "Modernising government". I paperet formuleredes en politik, der understreger ønsket om, at politiske beslutninger ("policy making") baseres på viden om, hvilke virkemidler og indsatstyper der virker. Læring skal fremmes via styrket anvendelse af evidens og forskning samt via udvikling af nye evalueringsværktøjer (Cabinet Office 1999 , s. 17 og 20). To år senere udvidede regeringen perspektivet til også at inkludere ønsket om, at praksis og opgavevaretagelse ("policy delivery") baseres på evidens (Cabinet Office Performance and Innovation Unit, 2001).

De politiske oplæg blev efterfølgende fulgt op dels ved at give økonomisk støtte til allerede eksisterende evidensproducerende organisationer, $\mathrm{fx}$ the Evidence for Policy and Practice Information and Co-ordinating Centre (EPPI) på Institute of Education, University of London, dels ved at etablere nye organisationer, blandt andet Social Care Institute for Excellence (SCIE). I 2001 karakteriserede William Solesbury udviklingen som "a peculiarly British affair" (Solesbury, 2001, s. 6). Der var uden tvivl noget om snakken på dette tidspunkt, men her 10 år senere er situationen en anden. Ønsket om at fundere politikog praksisudvikling på evidens er spredt til en række lande, herunder de nordiske.

\section{Rejsen til Skandinavien}

Nordiske forskere var involveret i tilblivelsesfasen i både Cochrane og Campbell, og nordiske centre blev hurtigt etableret med base i Danmark. Det Nordiske Cochrane Centre, der er lokaliseret på Rigshospitalet, blev således etableret i efteråret 1993 samtidig med det internationale samarbejde, og Det Nordiske Campbell Center, nu SFI Campbell, Nordisk Campbell Center, der er lokaliseret på SFI, Det Nationale Forskningscenter for Velfærd, blev etableret i 2002.

I begge tilfælde var eksisterende internationale forskningsnetværk en vigtig forudsætning for, at evidenstænkningen "rejste ind" i Norden. Nordiske forskere var fra starten med i diskussionerne om udviklingen af det internationale samarbejde, og disse var efterfølgende i stand til at sikre støtte og tiltrække ressourcer til etableringen af de nordiske centre i Danmark.

Evidensbevægelsens institutionelle forankring i Danmark blev således bestemt af de eksisterende forskningsbaserede netværkskonfigurationer. Det Nordiske Cochrane Centre blev via en klinisk forsker med kompetence inden for metaanalyse forankret på et hospital tæt på den kliniske forskning, mens Det Nordiske Campbell Center via en forsker med kom- 
petence inden for socialforskning blev forankret på et sektorforskningsinstitut.

Tilblivelsesomstændighederne udlagde nogle spor for den efterfølgende institutionelle udvikling i Danmark. Det Nordiske Cochrane Centre blev svagt koblet til sundhedsområdets sektorforskning og til den medicinske teknologivurdering i regi af Sundhedsstyrelsen, der benytter forskningsoversigter som et af dens vidensinput. Det Nordiske Campbell Center fik til opgave at producere evidensbaseret viden vedrørende social- og velfærdspolitiske indsatser, mens centrets indsats på det uddannelsesmæssige og det kriminologiske felt, der også dækkes af det internationale Campbell-samarbejde, er begrænset til at formidle den viden, der produceres internationalt.

Udviklingen gav plads til etableringen i 2006 af en særskilt evidensproducerende organisation på uddannelsesområdet kaldet Clearinghouse for uddannelsesforskning på Danmarks Pædagogiske Universitetsskole, Aarhus Universitet. Denne proces var mere drevet af politisk-administrative interesser, der brugte OECD som løftestang, end direkte af forskningsmæssige interesser (Foss Hansen \& Rieper, 2006).

Sverige har en lang tradition inden for evidensbevægelsen og var blandt de første både på sundhedsområdet og det sociale område. SBU (Kunskapscentrum för hälso- och sjukvården), som tidligere var det svenske medicinske teknologivurderingsinstitut, der blev oprettet i 1987, var en af støtterne, da man i 1993 på engelsk initiativ oprettede det internationale Cochrane-samarbejde. Også på det sociale område var Sverige tidligt ude, idet man fra den svenske socialstyrelse var med til at forberede oprettelsen af det internationale Campbell Collaboration og sad med i ledelsen heraf. På det sociale område blev Centrum för utvärdering av socialt arbete under den svenske socialstyrelse dannet i 1993 og indoptaget i Instituttet for udvikling af metoder i socialt arbejde, IMS, der blev oprettet i 2004.

Også i Norge er evidenstænkningen blevet opprioriteret i de senere år. Oprettelsen af Kunnskapssenteret i 2004 kan ses både som et resultat af dette og som en løftestang til fortsat opprioritering. Kunnskapssenteret, der har til opgave at bistå helsetjenesten med systematisk opdateret viden om medicinske og sundhedsfaglige metoder og teknologier, er en faglig uafhængig organisation i regi af Helsedirektoratet.
Kunnskapssenteret er den norske samarbejdspartner i både Cochrane- og Campbell-samarbejdet. Kunnskapssenteret er med virkning fra 2008 også vært for det internationale Campbell-samarbejde. I Norge synes evidensbevægelsen således forankret i en mere koordineret organisationsmodel end i både Danmark og Sverige.

\section{Organisering og arbejdsmåde internationalt}

Det internationale Cochrane-samarbejde er opbygget omkring en styregruppe og en række undergrupper kaldet reviewgrupper, metodegrupper og feltnetværk. Styregruppens opgave er at udvikle overordnede strategier og retningslinjer for samarbejdet. Reviewgrupperne, hvoraf der findes cirka 50, er samarbejdets vigtigste produktive enheder. Reviewgrupperne består af personer fra forskellige dele af verden med en fælles interesse $\mathrm{i}$ at udvikle systematiske reviews inden for et bestemt sundhedsfagligt emne som $\mathrm{fx}$ brystkræft, lungekræft, epilepsi eller anæstesi. Metodegrupperne, hvoraf der findes 11, består af personer med interesse for særlige metodiske spørgsmål. Der findes fx grupper for forskellige former for metaanalyse samt en gruppe for statistisk metode. Feltnetværkene er tværgående i forhold til flere reviewgrupper, fx findes der et feltnetværk for kræftsygdomme.

Den internationale organisering understøttes af regionale centre, herunder det nordiske center. Der findes 12 regionale centre, der dækker det meste af verden. De regionale centre er base for reviewgrupper og er herudover ansvarlige for blandt andet uddannelse og formidling.

Organiseringen af det internationale Campbell-samarbejde er kraftigt inspireret af Cochrane. Også her findes en styregruppe med et overordnet ansvar. Herudover er der etableret fire koordineringsgrupper, en for metode og en for hvert af de tre hovedområder uddannelse, kriminologi samt socialområdet og velfærd. Metodegruppen koordinerer metodemæssige spørgsmål for alle reviewgrupper, mens de tre tematiske grupper har ansvar for at koordinere de reviewgrupper, der henhører under deres tema. Mens reviewgrupperne i Cochrane synes relativt permanente over tid, er reviewgrupperne i Campbell mere ad hoc knyttet til udarbejdelsen af enkeltstående reviews. Campbell har også adopteret ideen med regionale centre, men indtil nu er der kun etableret ét sådant center nemlig det nordiske center (SFI Campbell). 
Cochrane har formuleret en række principper og værdier for sin praksis, som også Campbell har taget til sig. De væsentligste principper er at samarbejde, at undgå unødig duplikation i udarbejdelsen af reviews, at minimere bias, at ajourføre reviews løbende i takt med gennemførelsen af nye primærstudier, at stræbe efter relevans for beslutningstagere samt at sikre kvalitet. Begge organisationer har også udarbejdet retningslinjer for metodologi og udformning af såvel protokoller som reviews. Guidelines udarbejdet af Campbell refererer herudover til den fyldige "Cochrane Handbook for Systematic Reviews of Interventions". Cochrane metodologien er således en vigtig standard for Campbell samarbejdet. Blandt viften af forskningsoversigter er de systematiske forskningsoversigter og anvendelse af metaanalyse med afsæt i resultater fra lodtrækningsforsøg idealet. Både Cochrane og Campbell er således fortalere for, at evidensbevægelsen bør praktisere med afsæt i evidenshierarkiet, der rangordner forskningsdesign og betragter randomiserede kontrollerede forsøg som det bedste og det efterstræbelsesværdige (Rieper \& Foss Hansen, 2007).

\section{Databaser og formidlingsstrategier}

For at understøtte reviewarbejdet er både Cochrane- og Campbell-samarbejdet værter for databaser, der indeholder relevante primærstudier frem for alt baseret på randomiserede forsøgsdesign. Cochranes database CENTRAL indeholder således mere end 200.000 primærstudier, mens Campbells database SPECTR indeholder cirka 12.000 primærstudier. De to organisationer forsøger også på denne måde at hjælpe forskere, der ønsker at udarbejde reviews.

Organisationerne, der producerer reviews, bruger også kræfter på formidling. I en årrække var der i Danmark via Nordic Cochrane Centre offentlig adgang til det elektroniske Cochrane Bibliotek. Dette betød, at enhver, der måtte ønske det, gratis kunne få adgang til den database, der indeholder de mere end 2.000 reviews, der alt $i$ alt er udarbejdet $i$ det internationale Cochrane-samarbejde. Med argumentet, at denne service kun blev benyttet i begrænset omfang, blev den gratis offentlige adgang politisk sparet bort. I dag er gratis adgang i Danmark kun mulig for forskere og læger, der har adgang via fagbibliotekerne.

Via SFI Campbells hjemmeside er der direkte adgang til en database, der indeholder alle Campbellreviews. Databasen betegnes C2-RIPE, som er en forkortelse for Campbell Collaboration og Register of Interventions and Policy Evaluation. Herudover er der fra hjemmesiden adgang til andre relevante databaser, primært engelske, indeholdende reviews vedrørende både velfærd, uddannelse og kriminologi. Ud over sikring af adgang til databaser arbejder både Cochrane og Campbell med formidling via medier og konferencer.

Om resultaterne af formidlingsindsatsen er der begrænset viden. Er de udarbejdede reviews kendt blandt potentielle brugere? Hvordan vurderes de? Benyttes de og af hvem? Hvilke andre former for viden konkurrerer de med? Spørgsmål som der ikke kan gives klare svar på.

En rapport fra 2005 udarbejdet af DSI, Institut for Sundhedsvæsen, i samarbejde med Cochrane Hepato-Biliær-gruppen viste imidlertid, at der i relation til behandlingen af leverpatienter i Danmark er betydelige forskelle på forskningsbaseret viden og klinisk praksis, og at variation i klinisk praksis i øvrigt er almindeligt forekommende. Der gives eksempler på interventioner, der ifølge systematiske reviews er effektive, men som kun anvendes i praksis i begrænset omfang. Samtidig gives der eksempler på interventioner, der ifølge systematiske reviews ikke har nogen dokumenteret effekt, men som alligevel er udbredt i klinisk praksis. Kun få danske leverlæger benytter således Hepato-Biliær-gruppens systematiske reviews som grundlag for viden om kliniske interventioners effekt. I stedet udgør nationale og internationale meningsdannere samt medicinalindustrien de primære kilder til lægernes viden (Kürstein et al., 2005).

\section{Evidensproducerende organisationer forankret $i$ en bredere evidensbase}

Mens de internationale evidensproducerende organisationer tilstræber evidenshierarkiet, er der over tid etableret evidensproducerende organisationer, der arbejder med afsæt i en bredere evidensbase. Nævnes kan $\mathrm{fx}$ de tidligere omtalte engelske organisationer "The Evidence for Policy and Practice Information and Coordinating Centre" (EPPI) og "The Social Care Institute for Excellence" (SCIE) samt det ovenfor omtalte danske Clearinghouse for Uddannelsesforskning. 
Global: Evidens A. Globale reviews kun er universel inkluderende RCT's.
B. Globale reviews inkluderende en vifte af design.
Lokal: Evidens

er kontekstuel
C. Regionale eller nationale
reviews kun inkluderende
RCT's.
D. Regionale eller nationale reviews inkluderende primærstudier med en vifte af design.

\section{Figur 2. Evidenstcenkning}

De forskellige tilgange til evidensproduktion kan illustreres via figur 2. Evidens kan betragtes som henholdsvis global versus lokal, og evidens kan produceres med afsæt $\mathrm{i}$ henholdsvis en smal versus en bredere/bred evidensbase.

Med smal evidensbase menes, at systematiske reviews udarbejdes på grundlag af primærstudier, der helt eller overvejende er baseret på randomiserede kontrollerede forsøg (RCT), mens en bred(ere) evidensbase omfatter systematiske reviews, hvor grundlaget er primærstudier, der anvender flere forskellige forskningsdesign, fx sammenligningsgrupper, longitudinale registeranalyser og casestudiedesign.

Med global tænkning menes, at resultater fra forskningsoversigter (systematic reviews) er anvendelige generelt uanset geografi, målgruppe mv. (men selvfølgelig universel inden for forskningsoversigtens egen afgrænsning). Med lokal tænkning menes, at forskningsoversigter ikke kan tilbyde universel viden, men at deres resultater kun er gældende i specielle, lokale sammenhænge (kontekster), fx et bestemt land, en bestemt region, en bestemt kulturkreds eller for bestemte målgrupper. Vi er opmærksomme på, at man ved universelle forskningsoversigter også kan afgrænse til bestemte målgrupper, og at man kan opnå resultater, der viser variationer over geografiske områder. Men i udgangspunktet ved litteratursøgningen går man universelt til værks, og ambitionen er at finde generelt gældende resultater.

Cochrane- og Campbell-organisationernes evidenspraksis placerer sig altovervejende i felt A. Dog findes der eksempler på systematiske reviews, der er baseret på en bredere evidensbase, idet der inddrages resultater ikke alene fra RCT-baserede forskningsdesign, men også fra andre typer af kontrolgruppebase- rede design (felt B). Men disse eksempler er omdiskuterede i de to organisationer. Heroverfor findes der evidensproducerende organisationer, der arbejder ud fra en præmis om, at evidens er kontekstuel, at en given pædagogik fx kan være effektfuld i en given national skoletradition, men ikke nødvendigvis er effektfuld i andre kontekster. Af disse tager flere udgangspunkt i en bred evidensbase (felt D). Det gælder fx det engelske the National Institute for Health and Clinical Excellence (NICE), som primært arbejder med retningslinjer for det engelske sundhedsvæsen og på grundlag af en bred vidensbase. Og inden for det sociale område arbejder the Social Care Institute for Excellence (SCIE) under det engelske sundhedsministerium og administrationerne i Wales og Nordirland med at identificere og sprede viden om god praksis i det sociale arbejde i bred forstand. Det amerikanske What Works Clearinghouse (WWC), der blev etableret i 2002 af Departments of Education's Institute of Education Sciences, er et eksempel på en evidensproducerende organisation, der arbejder med en smal evidensbase og lokal, kontekstuel tænkning og dermed placerer sig i felt $\mathrm{C}$.

Eksistensen af forskelle i forskningstraditioner mellem USA og Europa, og måske ikke mindst Norden, udgør afsættet for en anden diskussion relateret til kontekst. Når man bevæger sig uden for det medicinske område og ind på områderne velfærd og uddannelse, synes der i Europa at være relativt få RCT-forankrede undersøgelser. Vælger evidensproducerende organisationer at konstruere reviewpraksis efter idealet om det randomiserede eksperiment, der er formuleret både i Cochrane og i Campbell, produceres konklusioner, der næsten udelukkende baserer sig på amerikanske erfaringer. Dette har i givet fald to konsekvenser. For det første bliver nordiske og europæiske erfaringer umiddelbart forbigået. For det 
andet rejser det det mere principielle spørgsmål om betydningen af forskelle i kulturel og samfundsmæssig kontekst: I hvilket omfang og på hvilke områder er det muligt at overføre resultater på tværs af kulturelle og politisk-administrative forskelle?

\section{Perspektiver på evidensbevægelsen}

Vi vil som nævnt afslutte med at se på etableringen af de evidensproducerende organisationer i et bredere samfundsmæssigt perspektiv, idet vi betragter udviklingen af evidensbevægelsen som indlejret i flere overordnede forandringstendenser i den offentlige sektor - både generelt internationalt og specifikt i Norden. Vi mener, at disse forandringstendenser indeholder bidrag til forståelse af, hvorfor det netop er i 1990'erne og først i 2000-årene, at særlige organisationer for udarbejdelse af forskningsoversigter er blevet etableret.

\section{Forandringernes form og indhold}

Evidensbevægelsens institutionalisering kan karakteriseres som et eksempel på en ikke-hierarkisk ændring, som er global, lokal og selvgroet (Beck Jørgensen, 2000, 316ff). Impulsen til forandring udspringer af efterkrigstidens vækst i forskningssystemerne og den deraf følgende betydelige øgning $\mathrm{i}$ omfanget af den videnskabelige produktion. I vidensamfundet arbejder stadig flere med forskning, og samtidig er kravet på den enkelte forsker for at publicere ligeledes stigende (se fx Olesen Larsen, 2003). Sammenlagt afstedkommer udviklingen en voldsom vækst i antallet af videnskabelige artikler, hvilket gør det til en betydelig udfordring at holde sig ajour med vidensudviklingen. Heri ligger en impuls til evidensbevægelsens udvikling. På denne baggrund formuleres et behov for at skabe transparens og overblik samt for løbende at vedligeholde dette. Impulsen gribes i denne sammenhæng først af forskningsentreprenører og internationale forskernetværk, der gør forandringsimpulsen til den grundlæggende idé bag Cochrane- og Campbell-samarbejderne.

\section{En ny form for vidensproduktion med konsekvenser}

Den institutionaliserede evidensbevægelse udgør en ny form for vidensproduktion, idet den praktiseres gennem udarbejdelsen af systematiske forskningsoversigter i en proces forankret i klare, men ofte også relativt snævre metodologiske idealer. Vidensformen er empirisk snarere end teoretisk og har fokus på effekt snarere end proces. Som den praktiseres af de internationale organisationer, er den universel og tenderer til at borttænke eventuelle betydninger af lokale kontekster. Den sætter fokus på spørgsmålet, om konkrete indsatser og interventioner virker eller ikke virker, men den har sjældent udsagnskraft til at besvare spørgsmålet om, hvorfor eller hvorfor ikke indsatser og interventioner virker.

En vidensform, som den evidensbevægelsen tilbyder, har et potentiale som beslutningsgrundlag i prioriteringer af, hvilke typer af indsatser der skal tilbydes borgerne. I dette perspektiv kan det ikke overraske, at forandringsimpulsen gribes af andre aktører frem for alt af politikere og deres forvaltninger. At impulsen gribes i det politisk-administrative system synes at have sammenhæng med, at den matcher både herskende værdier og andre pågående forandringer i den offentlige sektor.

I den offentlige sektor er værdierne faglighed og kvalitet fremherskende (Beck Jørgensen, 2003). Faglig professionalisme, der bygger på faglige uafhængige standarder baseret på forskning, har stigende betydning på alle niveauer i forvaltningen (Vrangbæk, 2003, s. 120). Den vidensform, som evidensbevægelsen tilbyder, matcher i denne sammenhæng forvaltningens værdiprofil og fagprofessionernes stræben efter at være vidensbaseret.

De evidensproducerende organisationers udarbejdelse af forskningsoversigter tilvejebringer faglighed ved at tilbyde systematisk oversigt over eksisterende viden. Herudover er der andre potentielle effekter. En vigtig bieffekt af udarbejdelse af systematiske reviews er således påpegning af mangler i tilgængelig viden. I den forstand har forskningsoversigter også et potentiale som prioriteringsredskab i styring af forsknings- og evalueringsindsats.

En anden mulig bieffekt kan være ændrede metodologiske prioriteringer. I USA har efterspørgslen efter RCT-forankrede primærstudier som input til udarbejdelse af systematiske forskningsoversigter på uddannelsesområdet således øjensynligt ført til omprioritering af visse forskningsbevillinger til fordel for RCT-designede undersøgelser. I Danmark har nogle store fonde (Forebyggelsesfonden og TrygFonden) i de senere år lagt vægt på evaluering og forskning, der er baseret på det randomiserede eksperimentdesign og evaluatorer og forskere har vist øget interesse for anvendelse af dette design. 


\section{Noter}

1. Vi har deltaget i en række konferencer i Campbell-regi, herunder i "The Fifth Annual Campbell Collaboration Colloquium" 2005, "Nordic Social Science Conference - the Effects of Public Policy" 2005, "Hvad Virker? Seminar om evidens i det sociale arbejde" 2005, 2006 og 2007 samt i en konference i OECD 2005 "Linking Evidence to Practice". Vi har interviewet Peter Gøtzsche, Det Nordiske Cochrane Center, Finn Børlum Kristensen, Center for Evaluering og Medicinsk Teknologivurdering, Merete Konnerup, Nordic Campbell Center, og Terje Ogden, Atferdssenteret, Oslo.

Der rettes en varm tak til stud.scient.pol. Yosef Bhatti for en omfattende og systematisk indsats med at søge og sammenstille materiale vedrørende de evidensproducerende organisationer

\section{Referencer}

Beck Jørgensen, T (2000). Forandringernes mangfoldighed: Empiriske og teoretiske konklusioner. I: M. Antonsen \& T. Beck Jørgensen (red.), Forandringer $i$ teori og praksis. Skiftende billeder fra den offentlige sektor. København: Jurist- og Økonomforbundets Forlag.

Beck Jørgensen, T (2003). På sporet af en offentlig identitet. Vaerdier $i$ stat, amter og kommuner. Magtudredningen. Århus: Aarhus Universitetsforlag.

Bhatti, Y et al. (2006). Evidensbevogelsens udvikling, organisering og arbejdsform En kortlcegningsrapport. AKF Forlaget.

Cabinet Office (1999). Modernising government. London.

Cabinet Office Performance and Innovation Unit (2001). Better Policy Delivery and Design: a Discussion Paper. London.

Campbell Collaboration (C2): www.campbellcollaboration.org (lokaliseret 22.2.2011)

Center for Evaluering og Medicinsk Teknologivurdering: http://www.sst.dk/Planlaegning\%20\%20kvalite
t/Medicinsk\%20TTeknologivurdering\%20MTV.aspx (lokaliseret 22.2.2011)

Chalmers, I (2001). Comparing the like: some historical milestones in the evolution of methods to create unbiased comparison groups in therapeutic experiments. International Journal of Epidemiology, 30, 1156-1164.

Cochrane, AL (1999) [1972]. Random Reflections on Health Services. London: Royal Society of Medicine Press Ltd.

Cochrane Collaboration: www.cochrane.org (lokaliseret 22.2.2011)

Davies, P (2004). Systematic reviews and the Campbell Collaboration. I: G. Thomas \& R. Pring (red.), Evidence-Based Practice in Education. New York: Open University Press.

Eraut, M (2004). Practice-based evidence. I: G. Thomas \& R. Pring (red.) Evidence-Based Practice in Education (s. 91-101). New York: Open University Press.

The Evidence for Policy and Practice Information and Co-ordinating Centre (EPPI-Centre): http://eppi.ioe.ac.uk/EPPIWeb/home.aspx (lokaliseret 22.2.2011)

Foss Hansen, H \& Rieper, O (2006). Evidensbevægelsen: Hvorfra, hvordan og med hvilke konsekvenser. Unge Pcedagoger, 2006(3), 27-34.

Hult, E (2006). Vetenskap i paketerad form. Framväxten av evidensbaserad medicin: I: C. Levay \& C. Waks (red.). Strävan efter transparens. Stockholm: SNS Förlag.

Kürstein P.; J. Kjellberg, L. Herbild, K.R. Olsen, M. Willemann, J. Søgaard \& C. Gludd (2005). Fra forskning til praksis. København: DSI Institut for Sundhedsvæsen.

Lihme, B (2005a). Kulturkamp. Social Kritik, 102 (17), 52.

Lihme, B (2005b). Leder i Social Kritik, 102 (17), 2-3. 
Mandag Morgen (2004). Virker velfcerden? - et debatoploeg om evidens og velfoerd. København.

Marthinsen, E (2004). Evidensbaseret praksis og ideologi. Nordisk Socialt Arbeid, 4 (24), 290-302.

Moos, L et al. (2005). Evidens i uddannelse? Social Kritik, 102 (17), 53-57.

Nordic Campbell (NC2):

http://www.sfi.dk/Default.aspx?ID=137 (lokaliseret 22.2.2011)

Nordic Cochrane Centre: www.cochrane.dk Social Care Institute for Excellence (SCIE): www.scie.org.uk/ (lokaliseret 22.2.2011)

Oakley, A (2000). A Historical Perspective on the Use of Randomized Trials in Social Science Settings. Crime and Delinquency, 46 (3), 315-329.

Oakley, A et al. (2005). The politics of evidence and methodology: lessons from the EPPI-Centre. Evidence and Policy, 1 (1), 5-31.

Olesen Larsen, P (2003). Forskningens Verden. Prydhave, nyttehave, vildnis. Århus: Aarhus Universitetsforlag.

Pawson, R (2002). Evidence-based Policy: The Promise of Realist Synthesis. Evaluation, 8 (3), 340358.
Petticrew, M \& Roberts, H (2006). Systematic Reviews in the Social Sciences. A Practical Guide. Malden: Blackwell Publishing.

Rieper, O \& Foss Hansen, H (2007). Metodedebatten om evidens. AKF Forlaget, København.

Shadish, WR, Chacón-Moscoso, S \& Sánchez-Meca, J (2005). Evidence-based Decision Making: Enhancing Systematic Reviews of Program Evaluation Results in Europe. Evaluation, 11 (1), 95-109.

Solesbury, W (2001). Evidence Based Policy: Whence it Came and Where it's Going. ESRC UK Centre for Evidence Based Policy and Practice: Working Paper 1.

Thomas, G (2004). Introduction: evidence and practice. I: G. Thomas \& R. Pring (red.) Evidence-Based Practice in Education (s. 1-18). New York: Open University Press.

Vrangbæk, K (2003). Værdilandskabet i den offentlige sektor. Resultater fra en survey. I: T Beck Jørgensen (red.). På sporet af en offentlig identitet. Voerdier $i$ stat, amter og kommuner, s. 105-133. Magtudredningen. Århus: Aarhus Universitetsforlag. 